\title{
The resting potential of rat's corneal endothelial cells
}

\begin{abstract}
The endothelium is a single layer of cells extending over the inner surface of Descemet's membrane. Its sub cellular organization reflects that the endothelium is extremely active metabolically. It functions as a regulator of corneal water content. Endothelium cells are mitochondria-rich and represent an active metabolic pump that carries out this function in conjunction with the tear film. The cornea must remain relatively dehydrated to retain its transparency. If the water content of the ground substance increases significantly, the stroma will be- come swollen and opaque, and the two most important optical functions, transparency and refractive power, will be severely compromised. The cornea is transparent, but the mechanism whereby corneal transparency is maintained is not known. The factors believed to contribute to its clarity may be divided into two categories: ${ }^{1}$ the physical arrangement of the fibers and cells, and ${ }^{2}$ their state of hydration. Although many studies have been performed about corneal transparency, there are some gaps to be full field. We performed 50 experiments on corneal preparations of Sprague-Dawley rats and analyzed the presence or absence of electrical sign by recording its voltage variations through one two pore electrode connected to a Grass polygraph. This study aims to register and quantify the resting potential of endothelial cells, as well as bring an important contribution to the knowledge of the normal physiology of the corneal endothelial cells.
\end{abstract}

Keywords: cornea, corneal endothelium, resting potential, endothelial cells, rats
Volume 3 Issue I - 2015

\author{
Luiz Reis Barbosa Júnior,Vinicius Vanzan, \\ Adalmir Morter Dantas \\ Biophysics Institute Carlos Chagas Filho Federal, University of \\ Rio de Janeiro, Brazil
}

\section{Correspondence: Luiz Reis Barbosa Júnior, Biophysics} Institute Carlos Chagas Filho, Universidade Federal do Rio de Janeiro RuaRodolpho Paulo Rocco 255, CidadeUniversitária, Ilha do Fundão, Rio de Janeiro - RJ - Brazil, Tel (55 2I) 3938-9600, Email luiz_reis@hucff.ufrj.br

Received: August 31, 2015 | Published: October 12, 2015

\section{Introduction}

The endothelium of cornea is a special type of epitelial tissue which is formed of a monolayer of pavement cells, of hexagonal form, and applied on the posterior surfasse of the posterior limiting membrane or Descemet membrane. ${ }^{1}$ The nucleumis oval and measuresabout $7 \mu \mathrm{m}$ in diameter and its located centrally in the cell. In the lateral region, the endothelial cells get in contact with each other, binding themselves through junctional complexes. The tight junctions bind the cells among themselves, forming an impermeable barrier, due to the fusion of the external leaf lets of the membranes of the contiguous cells with obliteration of the intercellular space, avoiding the transit of material in the cellular space through the endothelium. ${ }^{2}$

All animal cells maintain a voltage difference across their cell membranes, as well as some organelle membranes, such as the mitochondrial membrane. This voltage difference represents a source of potential energy that cells can harness to move molecules across membranes. The voltage difference is termed the resting membrane potential difference, or the membrane potential, for short. Membrane potential can be measured using a thin recording micro electrode encased in a very fine tipped glass pipette that can be inserted through the cell membrane into the cell. The microelectrode is connected by a voltmeter to a reference electrode that is immersed in the solution outside the cell. The voltmeter measures the voltage drop across the circuit caused by the membrane potential in $\mathrm{mV}$. In the most animal cells, the membrane potential is between -5 and $-100 \mathrm{mV}$. By convention, the membrane potential is expressed relative to the voltage outside the cell; thus, the negative value for $\mathrm{mV}$ means that the interior of the cell membrane is more electro negative than the cell membrane.

An endothelial cell without stimulus has a difference in the electric charge of its membrane called resing potential. There is a record of voltage difference when a micro electrode is placed on the outer surfasse of the endothelial cell membrane, and another, on the inner surfasse. The difference is of about 40 to 50 milli volts. Although actually the charge of the extracellular side of membrane is positive, by convention it receives a zero charge. Therefore, the inner part of the membrane is of -40 to -50 milli volts in relation to the extracellular side. If we would continue with the records for a long period, the charge through the membrane would remain the same. This phenomenon is called resting potential of the membrane. ${ }^{3}$

\section{Materials and methods}

We performed 50 experiments on corneal preparations of SpragueDawley rats $(n=30)$. Immediately after decapitation the eyeballs were removed and sectioned around the limbus. The corneas were transferred to a chamber and infused with BSS (balanced salt solution) driven by a peristaltic pump in order to maintain the BSS flowing at a rate from 0.8 to $0.85 \mathrm{ml} / \mathrm{min}$. The temperature in the chamber was set at $30^{\circ} \mathrm{C}$ by means of a thermostatic bath. BSS is composed by $(\mathrm{mmol} / 1): \mathrm{Na}^{+} 160.0, \mathrm{Cl}^{-130.0}, \mathrm{HCO}_{3}-25.0, \mathrm{~K}^{+} 5.0, \mathrm{H}_{2} \mathrm{PO}_{4} 3.0$, $\mathrm{Mg}^{++} 1.0, \mathrm{Ca}^{++} 1.0$, Glucose 5.0, presenting $\mathrm{pH}=7.4$ and $305 \mathrm{~m} \mathrm{Osm} /$ $\mathrm{kg} \mathrm{H}_{2} \mathrm{O}$. The presence or absence of electrical signal was detected by recording its voltage variations through one two pore electrode connected to a Grass polygraph (Figure 1) and the statistical analysis was made by Graph Pad Prism 6.0. 


\section{Recording the membrane potential of a corneal endothelium cell}

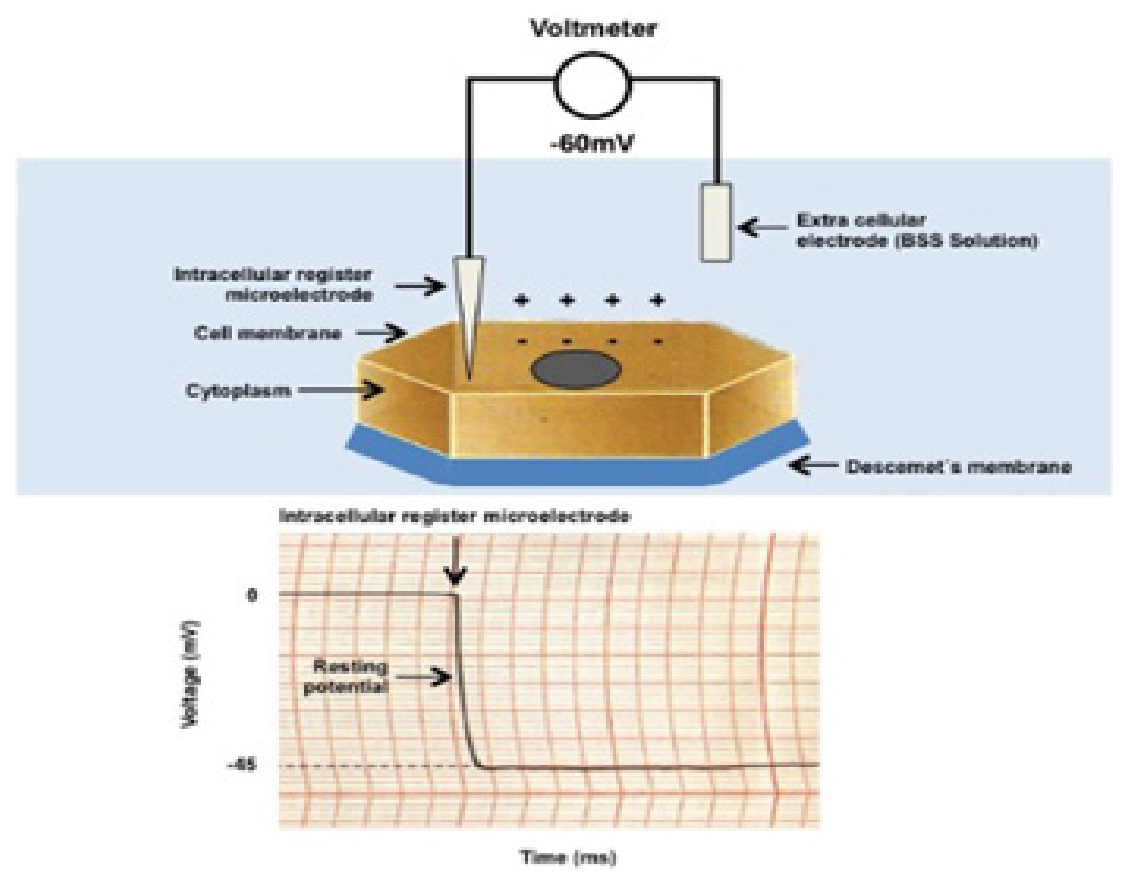

Figure I Up: Schematic endothelial cell penetrated by microelectrode. Below: Graphic demonstration of polygrapher at the exact moment of cell penetration.

\section{Results and discussion}

Our data demonstrated that the mean of endothelial resting potentials was $42.75 \mathrm{mV} \pm 3.05$ (Figure 2). All animal cells maintain a voltage difference across their cell membranes, as well as some organelle membranes, such as the mitochondrial membrane. This voltage difference represents a source of potential energy that cells can store to move molecules across membranes. The voltage difference is termed the resting membrane potential difference, or the membrane potential, for short.

\section{Endothelial Resting Potential}

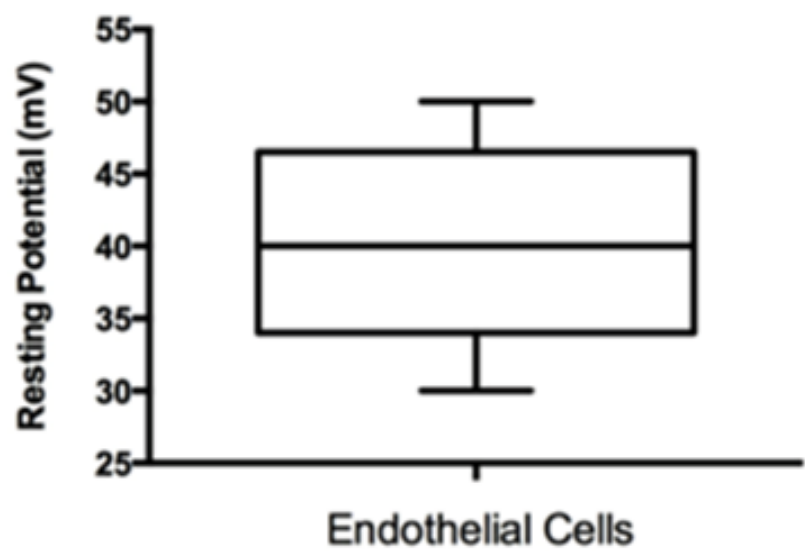

Figure 2 Graph showing mean, standard deviation and minimum and maximum values of resting endothelial potential.
The endothelial cell actively excretes the $\mathrm{HCO}_{3}{ }_{3}^{-}$ions in the anterior chamber. ${ }^{4}$ They are followed by a passive flow of $\mathrm{Na}^{+}$ions and water, assuring the deturgescence of the corneal stroma. Consequently, the stroma can be maintained in a state of relative dehydration necessary to its transparency. ${ }^{5}$ As we know the corneal endothelium is a hexagonal non-replicating monolayer of neural crest-derived tissue that regulates the hydration state of corneal stroma. A tissue containing large quantities of membrane-bound $\mathrm{Na}^{+}, \mathrm{K}^{+}$, ATPase with specialized inter cellular junctions that establish a pump-leak process in the maintenance of corneal deturgescence. Endothelium dysfunction is primarily a result of a reduction in $\mathrm{Na}^{+}, \mathrm{K}^{+}$- ATPase pump activity, with leads to a reduction in ion flux across the endothelium but the relative maintenance of barriers function through-out the course of disease.

\section{Conclusion}

It is evidente that the standing potential is determined by the concentrations difference of electric charges between the external and internal means of the endothelial cell. Since the cell potential is negative in relation to the exterior, this denotes that there is an excess of negative charges within the cell in relation to the exterior of the cell. ${ }^{6}$ One of the causes of the internal negativity of the resting cells is the presence in its interior of impermeable anions to the cellular membrane: firstly, the proteins and, secondly, the phosphates. However, the most important causal fator for the standing potential genesis is the interior of the cell full of potassium, which is a positive ion actively bombed into the intra cellular mean. As with all living cells, the endothelial cell of the cornea has an electric potential 
difference between the internal and external surfaces of its membrane, which value is from -40 to- $50 \mathrm{mV}$. Since the cell shows an electric potential difference, it is a real electric battery, a source of potential energy, thence, the electric potential difference.

The earliest observable change in endothelium results in Fuchs dystrophy. We are trying to show that when the lesion in the endothelium is small, the resting potential is small. In old rats we have the same process that is the standing potential is small. So we could say that the Fuchs degeneration is predisposed by age. The best of our search at the literature, we did not find any information about the resting potential of endothelial cells of the cornea. We found a measurement of $42.75 \pm 3.05$ and this study may bring a small contribution to the knowledge of the normal physiology of the corneal endothelial cells.

\section{Acknowledgments}

We would like to thank our laboratory technician Luciano C. Ferreira for all the work and dedication in this study.

\section{Conflicts of interest}

The author declares that there are no conflicts of interest.

\section{Funding}

None.

\section{References}

1. Farjo AA, Mcdermott ML, Soong HK. Corneal anatomy, Physiology and Wound Healing. In: Yanoff M, Duker JS(editors) Ophthalmology. Philadelphia, USA: Mosby-Elsevier. 2009:203-208.

2. Maurice DM. The structure and transparency of the cornea. J Physiol. 1957;136(2):263-286.

3. Hogan MJ, Alvarado JA, Weddell JE. Histology of the human eye. Philadelphia, USA: An atlas and textbook. WB Saunders. 1971;55-111.

4. Skou J. The influence of some cations on a adenosine triphosphatase from peripheral nerves. Biochim Biophys Acta. 1957;23(2):394-401.

5. Geroski DH, Edelhauser HF. Quantification of $\mathrm{Na} / \mathrm{K}$ ATPase pump sites in the rabbit corneal endothelium. Invest Ophthalmol Vis Sci. 1984;25(9):1056-1060.

6. Stiemke MM, Edelhauser HF, Geroski DH. The developing corneal endothelium: correlation of morphology, hydration and $\mathrm{Na} / \mathrm{K}$ ATPase pump site density. Curr Eye Res. 1991;10(2):145-156. 